\title{
Oceanography
}

CITATION

Chien, H., W.-S. Chiang, S.-J. Kao, J.T. Liu, K.-K. Liu, and P.L.-F. Liu. 2011. Sediment

dynamics observed in the Jhoushuei River and adjacent coastal zone in Taiwan Strait.

Oceanography 24(4):122-131, http://dx.doi.org/10.5670/oceanog.2011.100.

DOI

http://dx.doi.org/10.5670/oceanog.2011.100

COPYRIGHT

This article has been published in Oceanography, Volume 24, Number 4, a quarterly journal of The Oceanography Society. Copyright 2011 by The Oceanography Society. All rights reserved.

USAGE

Permission is granted to copy this article for use in teaching and research. Republication, systematic reproduction, or collective redistribution of any portion of this article by photocopy machine, reposting, or other means is permitted only with the approval of The Oceanography Society. Send all correspondence to: info@tos.org or The Oceanography Society, PO Box 1931, Rockville, MD 20849-1931, USA. 


\section{Sediment Dynamics Observed in the Jhoushuei River and Adjacent Coastal Zone in Taiwan Strait}

BY HWA CHIEN, WEN-SON CHIANG, SHUH-JI KAO, JAMES T. LIU, KON-KEE LIU, AND PHILIP L.-F. LIU

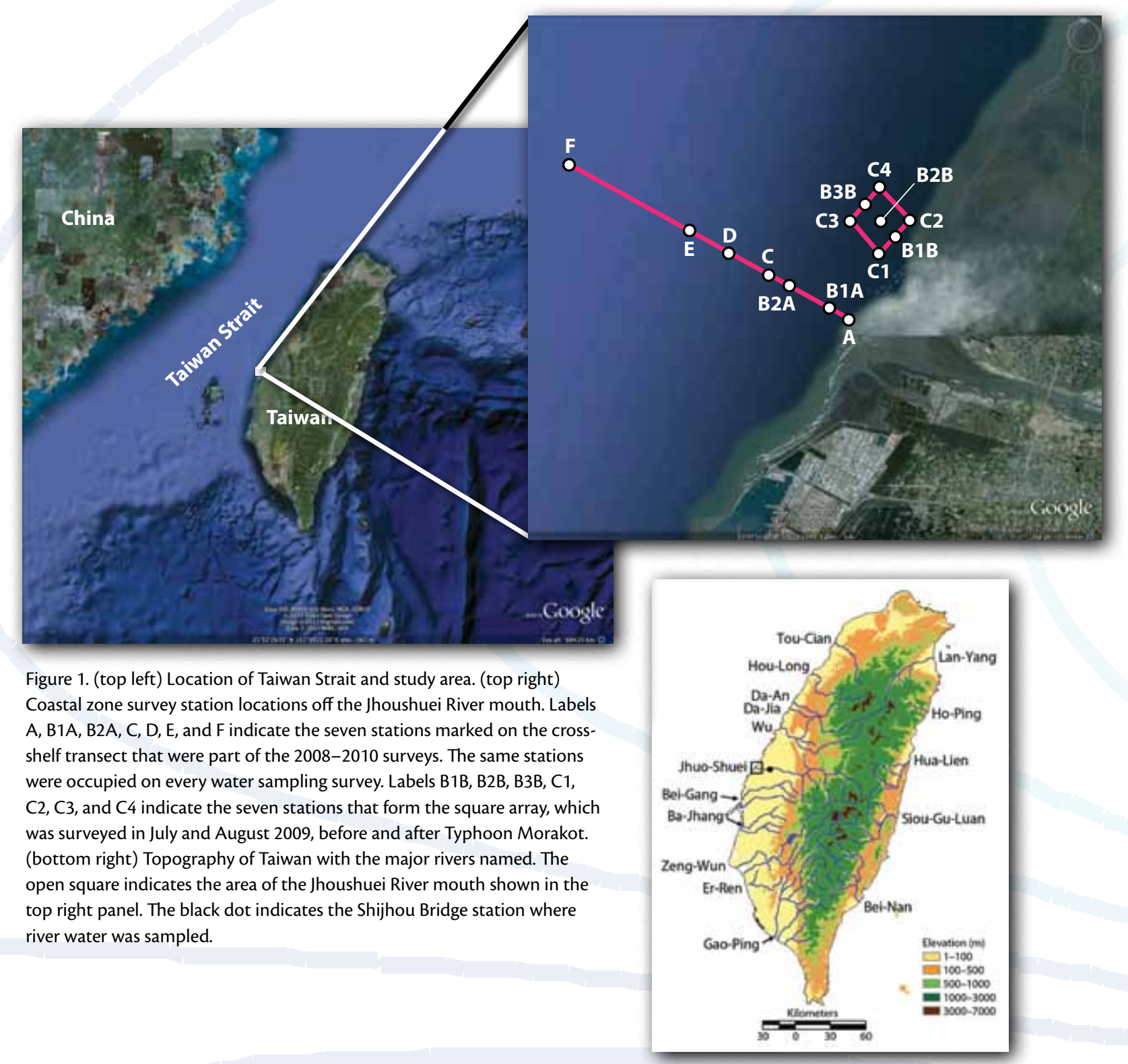


ABSTRACT. Taiwan's rugged, mountainous terrain, a result of active tectonics, and its monsoonal climate create conditions that produce the greatest sediment yield compared to all land surfaces on Earth. It is estimated that, on average, Taiwanese rivers discharge $\sim 150$ million tons of sediment annually into Taiwan Strait. The rivers discharge most of the sediment during the relatively short time periods of torrential rains often associated with typhoons, and thus the waters have a high mud fraction (fine-grained sediment, mainly composed of clay). The voluminous amount of sediment that rapidly accumulates near river mouths is dispersed effectively. On a longer time scale, there is persistent northward sediment transport. In this study, we examine the Jhoushuei River system, which has the largest average annual sediment load in Taiwan. The first survey was conducted in 2008, 40 hours after peak fluvial discharge caused by Typhoon Kalmaegi. We measured sediment discharge in the lower reach of the river channel and surveyed suspended sediment distribution in the coastal zone near the river mouth. During Kalmaegi's landfall on Taiwan, suspendedsediment concentration in the Jhoushuei River reached as high as $120 \mathrm{~g} \mathrm{~L}^{-1}$ and the estimated total sediment discharge was about 30 million tons. Since then, we have conducted surveys on four more occasions in the coastal zone near the river mouth, where we measured suspended-sediment concentrations and currents, and sampled surface sediments over several tidal cycles. The initial results shed light on the mechanism of efficient sediment dispersal during massive sediment-discharge events. Fine-grained sediments originally deposited near the river mouth following typhoon floods, generally in summer and fall, are dispersed during winter. The transport mechanism responsible for the sediment removal warrants further investigation.

\section{INTRODUCTION}

Earth's fluvial-shelf systems are often grouped into two categories in terms of sediment transport (e.g., Wright and Nittrouer, 1995). Large rivers such as the Amazon and Mississippi-Atchafalaya discharge into relatively wide and gently sloping continental shelves, so that most of the terrestrial sediment carried by these rivers is deposited in the estuaries and on adjacent shelves (e.g., Nittrouer et al., 1991; Walsh and Nittrouer, 2009), shaping the coastal geomorphology. By comparison, small rivers flowing through tectonically active mountain belts deliver most of their terrestrial sediment into the deep ocean either directly through flow within submarine canyons (e.g., Liu et al., 2006) or indirectly via temporary deposition on shelves followed by resuspension and subsequent transport to the deep seafloor in relatively short periods of time (i.e., several months to a few years; Milliman and Syvitski, 1992). This ephemeral nature of terrestrial sediment deposits (i.e., mud) in the ocean makes it challenging to predict their seabed properties and characteristics.

One of the major factors that determines the fate of fluvial sediment discharged into the coastal ocean is the effective density of the sedimentladen river plume relative to the ambient seawater. Prior process-based research efforts have mainly focused on large river systems (Amazon Shelf Sediment Study: Nittrouer et al., 1991; Mississippi-Atchafalaya system: for example, Draut et al., 2005) or mountainous rivers with moderate sediment discharge (Strata Formation on Margins [STRATAFORM]: Nittrouer and Kravitz, 1996; EUROSTRATAFORM: Sherwood et al., 2004). The sediment-laden river plumes in these cases are positively buoyant, and physical processes (Geyer et al., 2004) at the river mouth and on the adjacent shelf (e.g., frontal zone dynamics), along with flocculation, mainly control their initial deposition. The importance of small mountainous rivers to the total sediment discharge into the ocean has long been recognized (Milliman and Syvitski, 1992), but few international studies have been conducted to examine these systems.

The island of Taiwan is located in an active tectonic region with high seismic activity (Yu et al., 2001). The sources of most Taiwan rivers are at high elevations, descending almost 4,000 $\mathrm{m}$ within a relatively short distance before entering the coastal ocean (Figure 1). Taiwan has a subtropical climate with a mean annual rainfall of $\sim 2,500 \mathrm{~mm}$ that occurs mostly during typhoon events (four per year on average; Wu and Kuo, 1999). Typhoon-related floods often trigger landslides and significant fluvial erosion. Additionally, strong episodic seismic events tend to exacerbate the landslide problem (Dadson et al., 2005). Since the 1999 M $_{\mathrm{w}}$ 7.6 Chi-Chi earthquake, more than 20,000 landslides and debris flows have occurred in the western foothills of 
the Taiwan orogen (Hovius et al., 2000; Lin et al., 2004), causing a considerable increase in the sediment load carried by rivers. According to Milliman and Kao (2005), nine of the 15 "dirtiest" rivers in the world that have the potential to frequently reach the hyperpycnal flow level are located in Taiwan.

Although Taiwanese rivers discharge a very large quantity of sediment into Taiwan Strait, the measured sediment deposition within the strait proper does not seem to match the amount discharged (Kao et al., 2008). According to Milliman et al. (2007), the sediment deposited near the Jhuoshuei River mouth after Typhoon Mindulle (early July 2004) was ephemeral (especially the mud, or fine-grained, portion), possibly due to wave resuspension and subsequent northward transport by the Taiwan Warm Current. Other analyses suggest that a significant fraction of the Jhuoshuei sediment is deposited north of Taiwan Strait (Kao et al., 2008; Huh et al., 2011).

Due to the high sediment yield and the very dynamic nature of sedimentation, Taiwan's small mountainous rivers and coastal zone provide an excellent location to study sediment-transport processes that are critical to our overall understanding of the fate of land-derived sediment. Thus, the US Office of Naval Research (ONR) supported the project "Preliminary Investigations on the Fate of Terrestrial Sediments in the Coastal Ocean Discharged from Taiwanese Small Mountainous Rivers." Because the Jhoushuei River (also known as the Chosui River) is the most sedimentproductive river in Taiwan, the project gathered data to answer the following questions: How much sediment is discharged from the river? Where is the sediment deposited initially? Where does the sediment go after reworking by waves, tides, and currents? How much sediment remains on the shelves? How much sediment is eventually delivered to the deeper ocean? What controls the sediment's fate?

The Jhoushuei River originates in the middle section of the Central Range and flows westward to reach the sea in the middle part of Taiwan Strait (Figure 1). Its drainage area is $3,155 \mathrm{~km}^{2}$, with a peak altitude of $3,416 \mathrm{~m}$. Its
Figure 2. Photo of a field survey in the coastal zone off the Jhoushuei River mouth 40 hours after peak fluvial flow caused by Typhoon Kalmaegi in 2008. The sharp front between turbid and clear water is obvious at the boundary of the river plume. Sea-surface roughness varies across the front due to the convergence at the front's leading edge. river channel has an average gradient of $1 / 190$. Its mean annual runoff is $4.22 \times 10^{9} \mathrm{~m}^{3}$, with an average annual sediment discharge of $40 \pm 6 \mathrm{Mt}$ (Kao and Milliman, 2008). The tidal range on the adjacent shelf of the river mouth is $\sim 3 \mathrm{~m}$ on average. We conducted the first simultaneous observations of sediment discharge in the Jhoushuei River channel and sediment transport in the coastal zone near the river mouth shortly after Typhoon Kalmaegi in 2008. Since then, we have conducted repeated surveys of sediment in the water column as well as on the seafloor in the coastal zone near the river mouth. Here, we report highlights of these observations. The preliminary results shed light on the differences between sediment transport under extreme weather conditions and that under normal conditions.

\section{FIELD SURVEYS}

Five surveys in the vicinity of the Jhoshuei River mouth in the middle section of the western coast of Taiwan were conducted in the summers of 2008-2010. In 2008, heavy rainfall in the Jhoushuei watershed during the landfalls of Typhoons Kalmaegi and Jangmi resulted in hazardous flooding along the southwestern coast of Taiwan. During the passage of these typhoons, the Water Resource Agency (WRA) collected data on Jhoushuei River fluvial discharge and suspended-sediment concentration from the Shijhou Bridge. Field observations in the coastal zone off the Jhoushuei River mouth were gathered immediately after Typhoon Kalmaegi's passage (Figure 2). A bottom station, equipped with an array of optical backscatter sensors and acoustic Doppler current profilers (ADCP), was set up to 
measure suspended-sediment concentrations, waves, and tidal currents. Concurrent measurements by towed ADCP and observations using an optical turbidity sensor and a conductivitytemperature-depth (CTD) probe were collected along with surface, mid-depth, and bottom water samples. Figure 1 shows the location of the cross-shelf survey transect and sampling stations. The vessel traveled back and forth along the transect six times, collecting current and suspended-sediment data as well as water and sediment samples over the tidal cycle.

In 2009, Typhoon Morakot brought unprecedented heavy rain to central Taiwan, causing one of the most serious flooding catastrophes in the last 50 years. Offshore surveys were conducted before and after the typhoon (Figure 1). Survey water depths at each site range from $5 \mathrm{~m}$ to $15 \mathrm{~m}$. Water samples at several depths as well as seabed sediment samples were collected. During a tidal cycle, watercolumn sampling was repeated six times and sediment sampling was repeated three times, so that the variations related to the tidal elevation would be distinguished. The suspended-sediment samples from water column and seabed samples were sieved to sort out grainsize distributions.

\section{RESULTS AND DISCUSSION}

\section{River Discharge of Sediment}

Figure 3a shows the continuous Jhoushuei River runoff and discrete suspended-sediment concentration (SSC) data for 2008 collected from the Shijhou Bridge by the WRA. Thirtyfive suspended-sediment samples were analyzed, 17 of which were collected during the high-flow season from June
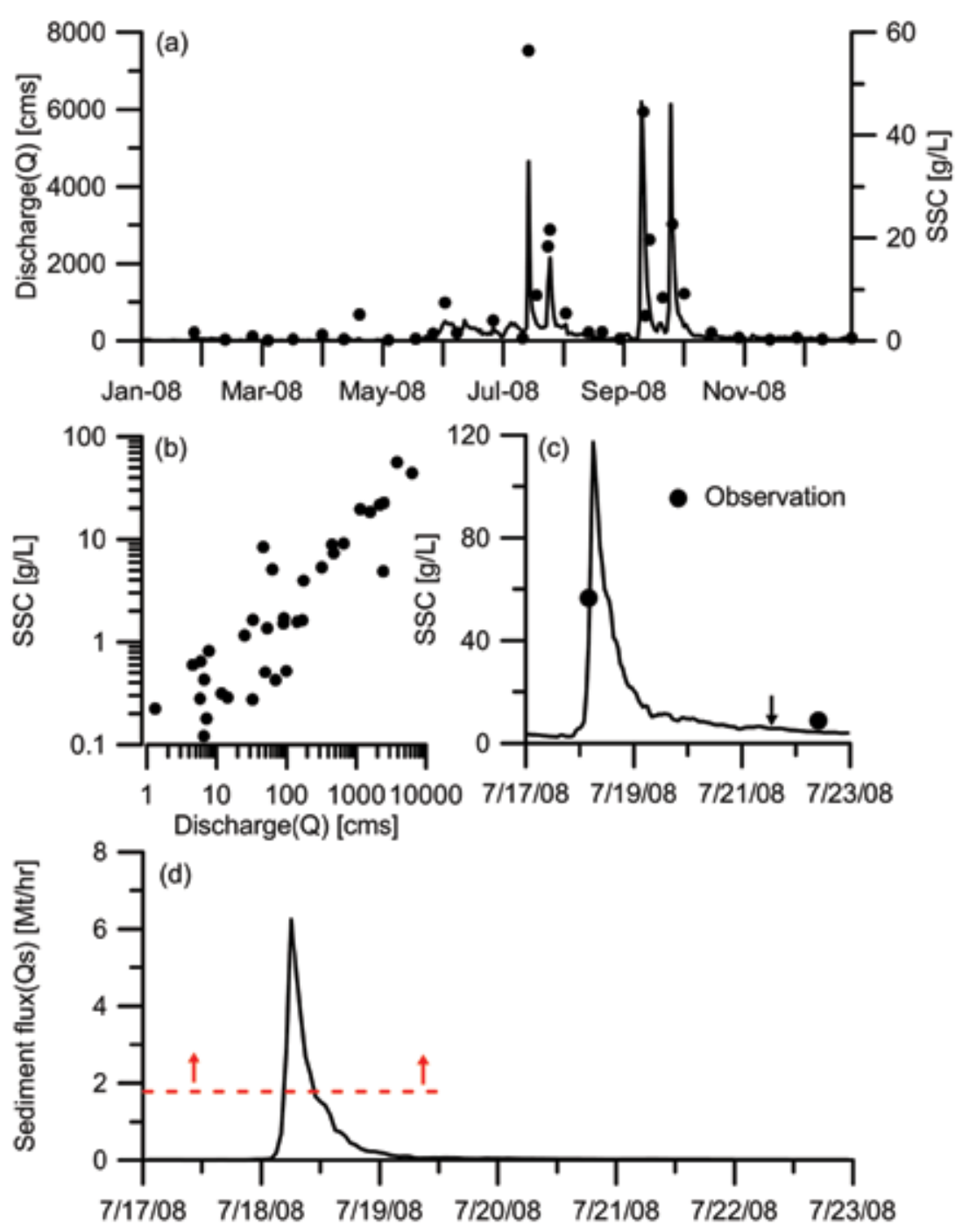

Figure 3. Time series of river water discharge, sediment discharge, and the suspended-sediment concentration (SSC) variation for 2008 for the Jhoushuei River collected from the Shijhou Bridge by the Water Resources Agency. (a) River water discharge and SSC data. (b) SSC-discharge rating curve. (c) Dischargederived SSC time series (black arrow indicates the beginning of the field survey in the coastal zone). (d) Estimated sediment discharge for the 2008 Typhoon Kalmaegi event. The red arrows indicate the period of the typhoon.
Hwa Chien is Assistant Professor, Institute of Hydrological and Oceanic Sciences, National Central University, Jhongli, Taoyuan, Taiwan. Wen-Son Chiang is Associate Researcher, Tainan Hydraulics Laboratory, National Cheng-Kung University, Tainan, Taiwan.

Shuh-Ji Kao is Research Fellow, Research Center for Environmental Changes, Academia Sinica, Nankang, Taipei, Taiwan. James T. Liu is Professor, Institute of Marine Geology and Chemistry, National Sun Yat-sen University, Kaohsiung, Taiwan. Kon-Kee Liu (kkliu@ ncu.edu.tw) is Professor, Institute of Hydrological and Oceanic Sciences, National Central University, Jhongli, Taiwan. Philip L.-F. Liu is Class of 1912 Professor of Engineering, School of Civil and Environmental Engineering, Cornell University, Ithaca, NY, USA. 

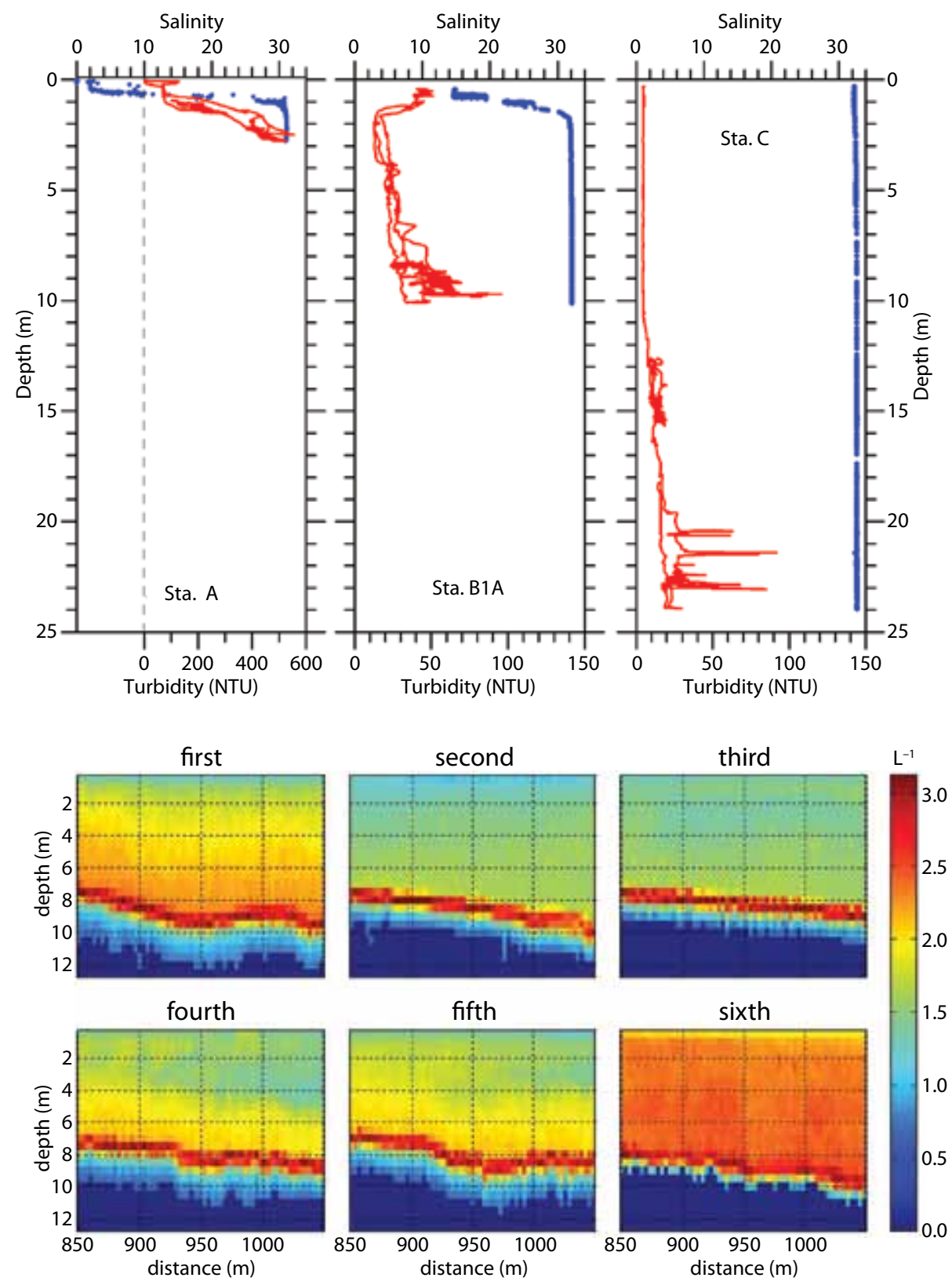

Figure 4. (top panels) Salinity (blue) and turbidity (red) measured with conductivitytemperature-depth (CTD) sensors at three stations in the coastal zone off the Jhoushuei River mouth. The vertical dashed line shows the origin of the turbidity axis, which is offset from that of the salinity axis to avoid too much overlapping of the two curves for Station A. The high turbidity near the bottom indicates high suspended-sediment concentration (SSC) due to resuspension. Turbidity is plotted in Nephelometric Turbidity Units (NTU). The turbidity is converted to SSC following the empirical relationship obtained for each cruise. In this case, the relationship SSC $=4.01 \times \mathrm{OBS}^{0.9662}$ was used for the conversion, where SSC is in $\mathrm{mg} \mathrm{L}^{-1}$ and OBS is the observed turbidity (from optical backscatter sensors) in units of NTU. (Because the conversion relationship is not perfect and may result in more uncertainties, we present the original data so as to show the trend described in the text.) (bottom panels) Sections of suspended-sediment concentrations ( $\left.\mathrm{g} \mathrm{L}^{-1}\right)$ between Stations B1A and B2A (see Figure 1), derived from the intensity of acoustic Doppler current profiler (ADCP) signals recorded repeatedly along the transect. The first panel represents the observation starting at 09:20 on July 20, 2008, with a 95 -minute time difference between adjacent panels. High tide occurred at 12:00 (second panel) and low tide at 18:10 (sixth panel). to October. SSC values range from $0.08 \mathrm{~g} \mathrm{~L}^{-1}$ to $\sim 60 \mathrm{~g} \mathrm{~L}^{-1}$, covarying with water discharge. Note that the peak SSC occurred during the first flood of the year as a result of Typhoon Kalmaegi. It appears that a large amount of sediment that had been deposited on the riverbed was easily flushed downstream during flooding. Following Kao et al. $(2005,2008)$, we constructed a discharge-dependent SSC rating curve based on WRA measurements. The SSC shows a positive correlation with water discharge (Figure $3 \mathrm{~b}$ ), revealing three orders of magnitude variation, which is consistent with previous reports (e.g., Kao et al., 2008). Based on the rating curve, we generated an SSC time-series curve (Figure $3 \mathrm{c}$ ). The SSC reached a maximum of $\sim 120 \mathrm{~g} \mathrm{~L}^{-1}$ shortly after the onset of high-density riverine flow during Typhoon Kalmaegi. According to our estimation (Figure 3d), $\sim 26 \mathrm{Mt}$ of sediment was discharged within 24 hours of Typhoon Kalmaegi's landfall. Figure $3 \mathrm{c}$ indicates that the fluvial discharge might have sustained hyperpycnal flow for $\sim 24$ hours, when the SSC concentration exceeded $40 \mathrm{~g} \mathrm{~L}^{-1}$.

\section{Suspended Sediment Distribution} in the Coastal Zone

Although the coastal zone field survey was conducted about 40 hours after fluvial peak discharge, the river plume was still clearly visible, with a sharp front between the turbid plume and clear ambient coastal water (Figure 2). The sea-surface roughness exhibited visually significant differences across the frontal zone. The top panel of Figure 4 shows salinity (blue) and turbidity (red) profiles at the three stations close to the river mouth. The surface-layer salinity 
at Station A varied between zero and $\sim 9 \mathrm{psu}$, while the turbidity corresponded to SSC of 0-0.4 $\mathrm{g} \mathrm{L}^{-1}$. The surface-layer salinity at Station B1A was $~ 15$ psu and the SSC was $\sim 0.18 \mathrm{~g} \mathrm{~L}^{-1}$, indicating a rapid decrease in the river signal offshore. In fact, no trace of the river plume was observed at Station C, which is fewer than $8 \mathrm{~km}$ from the river mouth.

The rapid disappearance of observed river water offshore suggests that most of the river runoff was entrained in the along-shore flow instead of jetting into Taiwan Strait. Strong alongshore tidal currents (up to $1.5 \mathrm{~m} \mathrm{~s}^{-1}$ as measured by bottom-mounted ADCP) dispersed and diluted the plumes, which formed secondary and tertiary fronts that could be identified in satellite images. Across these fronts, 72 seawater samples were collected along the transect (Figure 1). The measured maximum SSC reached $2.4 \mathrm{~g} \mathrm{~L}^{-1}$ at $50 \mathrm{~cm}$ above the seabed at station $\mathrm{A}$ about $2 \mathrm{~km}$ from the river mouth. The SSC of these water samples was used to calibrate the optical backscatter sensors (OBS) and acoustic sensors for SSC measurements. The bottom panels of Figure 4 show the SSC distribution obtained from the OBS and the acoustic sensor. The second panel shows the condition at high tide, when the flooding tide brought in clean seawater with low SSC. The sixth panel shows low tide, when the ebbing tide brought more suspended sediment from the river runoff. The high-SSC nepheloid layer observed near the bottom is consistent with the turbidity profiles observed at Stations B1A and C (top panel of Figure 4).

Compared to the SSC of 8-26 $\mathrm{g} \mathrm{L}^{-1}$ observed in the river channel at the Shijhou Bridge, the SSC in the water column adjacent to the river mouth was considerably lower. The percentages of river water in the surface layer of Stations A and B1A, as calculated from salinity, should be, respectively, $72-100 \%$ and $53 \%$. Dilution by clean seawater would yield an SSC of more than 5.8 and $4.2 \mathrm{~g} \mathrm{~L}^{-1}$, respectively. By comparison, SSCs in the surface layers of Stations A and B1A were less than one-tenth of the calculated minimum values. The drastic decrease of SSC from the river channel to the offshore station is much greater than the dilution effect. Hence, a majority of the sediment load probably settled out of the water column once the river runoff reached the coastal zone. This notion is supported by the dramatic increase in SSC toward the bottom at Station A (Figure 3 top panel). If two-thirds of the estimated total sedi-

\section{Sediment Dispersion in}

the Coastal Zone

The tidal current in the mid-section of Taiwan Strait could reach $1.5-2.0 \mathrm{~m} \mathrm{~s}^{-1}$ (Hu et al., 2010) during spring tides. It is worthwhile to explore the effects of strong tidal currents on water mixing, river plume oscillation, and resuspension of seabed sediment. These processes directly influence sediment transport in the coastal zone. Figure 5 is an example of the temporal evolution of SSC distribution near the river mouth at different phases of a tidal cycle as observed in July 2009 , when river discharge was relatively low as compared to typhoon conditions. Each panel represents a 40-minute interval. The river mouth is about $2 \mathrm{~km}$ from the lower-right corner of the area shown in each panel (Figures 1 and 5).

The SSC distribution indicates that, at ment discharge (30 Mt) of the Jhoshuei River during this typhoon event settled over an area of $\sim 6 \mathrm{~km}^{2}$, seabed sediment accretion should be as thick as $1.0 \mathrm{~m}$. However, when a bottom topography survey was carried out on October 5 , 2.5 months after the typhoon, no such deposit was found. This observation clearly demonstrates the very dispersive nature of sediment deposition, and is worthy of further investigation. slack water between ebb and flood, the high-SSC region occurred more inshore, closer to the river mouth (Figure 5, panels 1-3), indicating the dominance of fluvial sediment discharge. As the tidal current speed increased, the highSSC water was located more offshore (Figure 5, panels 4 and 5), indicating that the suspended sediment load in the water column was resuspension-dominated. This observation is reasonable 
because in the more offshore region, where the water is deeper, the tidal current speed is faster due to less bottom friction. Consequently, the greater current speed induces stronger resuspension of seabed sediment.

We have also observed that, during flooding events, sediment is transported in a different manner, distinct from the resuspension processes illustrated above. In contrast to the more stratified water column structure during resuspension, the well-mixed water and sediment effluent discharged from the river during flooding events prevents water-column stratification, enhancing turbulence that, in turn, sustains sediment suspension and efficient dispersal.

\section{Grain-Size Distributions}

Grain-size distributions of suspended sediment, as well as seafloor surface sediment, are represented by mean diameters corresponding to the accumulative percentiles of 10 to $90 \%$ along the distribution from the finest to the coarsest grains, designated as $\mathrm{d}_{10}, \mathrm{~d}_{25}$, $\mathrm{d}_{50}, \mathrm{~d}_{75}$ and $\mathrm{d}_{90}$. For suspended sediment, several probability models were adopted to describe grain-size distribution, and the quality of fit was tested accordingly. Perfect fits to observations are produced by the nonlinear Weibull model, which is governed by two parameters-shape and scale. The shape of the probability density function for grain size is highly dependent on the SSC (Figure 6, top panel). With increasing SSC, the portion of coarser particles increases, as indicated by the lengthening tail of the size distribution curve. This result is consistent with the notion that, as the SSC increased during rising tidal current velocity, more coarse-grained sediment was resuspended. On the other
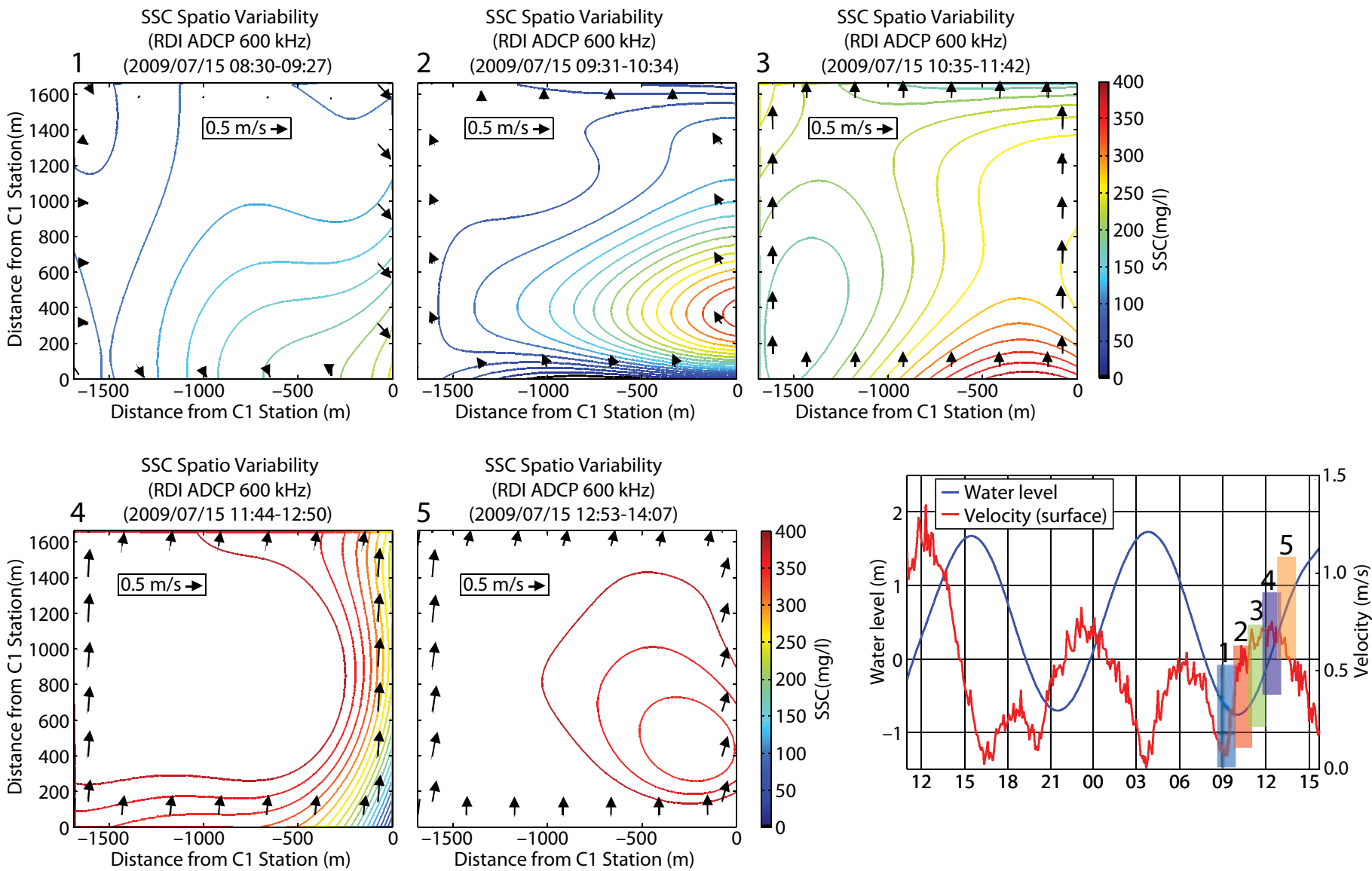

Figure 5. Temporal evolution of SSC distribution (40 minutes between each of the five consecutive panels) near the Jhoshuei River mouth observed in July 2009, demonstrating the tidal effect. The data represent survey results obtained from the square cruise track shown in Figure 1. The lower-right corner of each panel was closest to the river mouth (about $2 \mathrm{~km}$ away). SSC contour lines are in $\mathrm{mg} \mathrm{L}^{-1}$. The black arrows in each panel indicate the current speed and direction observed by ADCP. The lower-right panel shows the tidal elevation (blue curve) and current speed (red curve). The vertical bars denote the time period corresponding to panels $1-5$. 
hand, when the tidal current subsided, the large particles fell out of the water column preferentially due to their higher settling velocity.

Interesting features were also found in surface sediment grain-size distributions observed during surveys before (Table 1) and after (Table 2) the severe flooding catastrophes in Taiwan caused by Typhoon Morakot in 2009 (see Figure 1 for sampling locations). For the July 2009 survey before the typhoon, surface sediment was collected from three coastal stations off the Jhoushuei River mouth (Table 1). The mean grain sizes of all samples ranged from $0.06 \mathrm{~mm}$ to $0.19 \mathrm{~mm}$, characterizing the surface sediments as silt to fine sand. For the August 2009 survey after the typhoon, surface sediments were collected from five coastal stations near the river mouth. Table 1 lists the grain-size distributions. The mean grain sizes ranged from $0.04 \mathrm{~mm}$ to $0.06 \mathrm{~mm}$, indicating that the surface sediment was mostly silt. The surface sediment was finer than that found during the previous survey, and the grain size was more uniform.
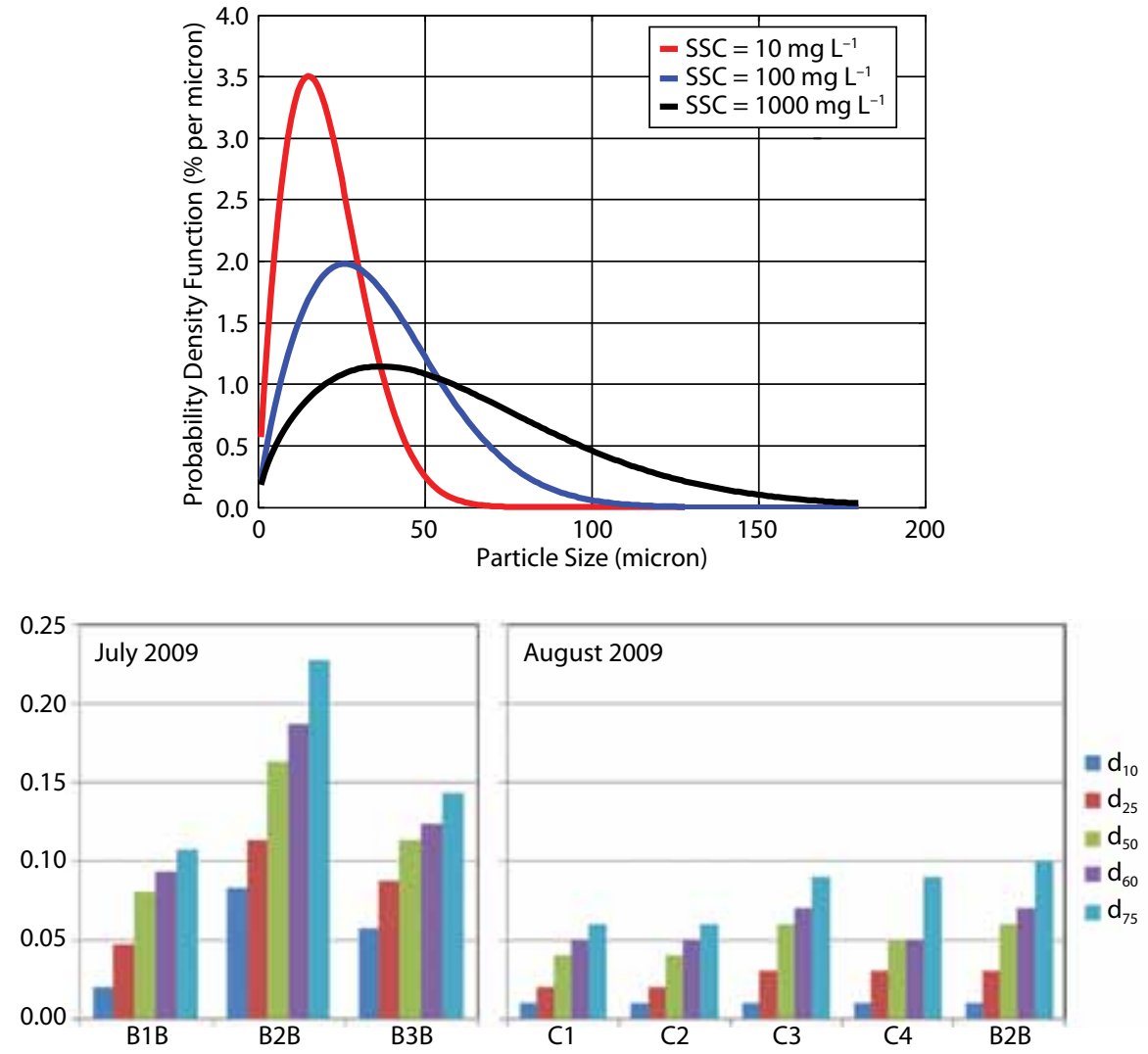

Figure 6. Grain-size distribution observed in the water column (top panel) and in seafloor surface sediment (lower panel) in summer 2009. (top panel) Grain-size distributions of suspended sediment during tidal resuspension observed in the water column off the Jhoushuei River mouth. (See text for more details.) (bottom panel) Comparison of grain-size $(\mathrm{mm})$ distributions in the surface sediment of the coastal zone near the Jhoushuei River mouth before and after Typhoon Morakot. The finer surface sediment after the typhoon indicates freshly deposited sediment from river discharge. In the following summer (2010), the grain-size distribution was back to the normal pattern seen in July 2009, indicating efficient dispersion of the fine sediment in fall and winter after the typhoon season.

Table 1. Grain-size distributions in surface sediments observed at different tidal stages at three coastal stations (B1B-B3B) near the Jhoushuei River mouth in July 2009 before Typhoon Morakot. The listed data are in units of mm. See Figure 1 for station locations.

\begin{tabular}{|c|c|c|c|c|c|c|c|c|c|}
\hline \multirow{2}{*}{$\begin{array}{c}\text { Grain-size } \\
\text { parameters }\end{array}$} & \multicolumn{3}{|c|}{ Period 1 (ebbing) } & \multicolumn{3}{c|}{ Period 4 (flooding) } & \multicolumn{3}{c|}{ Period 6 (near high tide) } \\
\cline { 2 - 11 } & B1 B & B2B & B3B & B1B & B2B & B3B & B1B & B2B & B3B \\
\hline $\mathrm{d}_{50}$ & 0.10 & 0.19 & 0.10 & 0.09 & 0.14 & 0.12 & 0.05 & 0.16 & 0.12 \\
\hline $\mathrm{d}_{10}$ & 0.03 & 0.10 & 0.03 & 0.02 & 0.08 & 0.07 & 0.01 & 0.07 & 0.07 \\
\hline $\mathrm{d}_{25}$ & 0.07 & 0.13 & 0.08 & 0.05 & 0.10 & 0.09 & 0.02 & 0.11 & 0.09 \\
\hline $\mathrm{d}_{60}$ & 0.11 & 0.21 & 0.11 & 0.11 & 0.16 & 0.13 & 0.06 & 0.19 & 0.13 \\
\hline $\mathrm{d}_{75}$ & 0.12 & 0.24 & 0.13 & 0.13 & 0.21 & 0.15 & 0.07 & 0.23 & 0.15 \\
\hline $\mathrm{C}_{\mathrm{U}}$ & 4.03 & 2.23 & 3.52 & 5.51 & 2.01 & 1.77 & 6.00 & 2.50 & 1.74 \\
\hline $\mathrm{d}_{\mathrm{m}}$ & 0.09 & 0.19 & 0.10 & 0.10 & 0.16 & 0.13 & 0.06 & 0.17 & 0.13 \\
\hline
\end{tabular}

$d_{50}=$ Grain size at $50^{\text {th }}$ percentile $(\mathrm{mm})$. Other percentiles are also listed. $d_{m}=$ mean grain size $(\mathrm{mm}) . C_{U}=$ Coefficient of uniformity. 
Table 2. The same as Table 1 except observed at five coastal stations in August 2009 after Typhoon Morakot. See Figure 1 for station locations.

\begin{tabular}{|c|c|c|c|c|c|}
\hline $\begin{array}{c}\text { Grain-size } \\
\text { parameters }\end{array}$ & $\mathrm{C} 1$ & $\mathrm{C} 2$ & $\mathrm{C} 3$ & $\mathrm{C} 4$ & B2B \\
\hline $\mathrm{d}_{50}$ & 0.04 & 0.04 & 0.06 & 0.05 & 0.06 \\
\hline $\mathrm{d}_{10}$ & 0.01 & 0.01 & 0.01 & 0.01 & 0.01 \\
\hline $\mathrm{d}_{25}$ & 0.02 & 0.02 & 0.03 & 0.03 & 0.03 \\
\hline $\mathrm{d}_{60}$ & 0.05 & 0.05 & 0.07 & 0.05 & 0.07 \\
\hline $\mathrm{d}_{75}$ & 0.06 & 0.06 & 0.09 & 0.09 & 0.10 \\
\hline $\mathrm{C}_{\mathrm{u}}$ & 6.00 & 6.00 & 6.00 & 4.51 & 6.00 \\
\hline $\mathrm{d}_{\mathrm{m}}$ & 0.05 & 0.04 & 0.06 & 0.06 & 0.06 \\
\hline
\end{tabular}

Although the typhoon flood should have brought more coarse-grained sediment to the coastal zone, the surface sediment was finer grained than under normal, nontyphoon conditions. Sorting of the freshly delivered sediment during settling likely caused the observed grainsize distribution.

In the summer of 2010 , no finegrained sediment was observed, implying that it had been dispersed offshore, leaving behind the coarser-grained sediment. Sediment transport was likely activated by energetic wind-wave action under the strong and persistent winter monsoon. Further surveys are required to check the validity of this hypothesis.

\section{SUMMARY AND CONCLUSIONS}

During passage of Typhoon Kalmaegi through Taiwan in 2008, the suspendedsediment concentration reached as high as $120 \mathrm{~g} \mathrm{~L}^{-1}$ in the Jhoushuei River, and the estimated total sediment discharge from the river was some 30 million tons in about three days. Although we began the survey shortly after passage of the typhoon, we did not observe very high SSC in the river plume a short distance from the river channel, where the SSC reached as high as $26 \mathrm{~g} \mathrm{~L}^{-1}$. This observation suggests rapid settling of suspended sediment once it reached the coastal zone. During the next survey 2.5 months after the event, we did not find a large accretion of sediments on the seafloor adjacent to the river mouth. It appears that sediment dispersal was very efficient, so that a majority of the discharged sediment was transported away from the coastal zone off the river mouth. Strong tidal currents were likely responsible for such action. After Typhoon Morakot in 2009, fine-grained sediment was observed to cover the seafloor in the coastal zone near the river mouth. In 2010, when this area was resurveyed, all the fine-grained sediment had disappeared, again demonstrating an efficient mechanism that transports sediment away from the river mouth. Further work is needed to examine in more detail the efficient sediment transport processes observed in Taiwan Strait.

\section{ACKNOWLEDGMENTS}

The US Office of Naval Research (ONR) and ONR Global supported this study through grant N00014-08-1-1049. The National Science Council of the Republic of China, National Central University, and National Cheng-Kung University provided additional support. We are grateful for valuable suggestions from C. Nittrouer and an anonymous reviewer. We also appreciate the help of T.-J. Hsu and S.-K. Hsu in developing the project. We acknowledge the technical support of C.-H. Lin.

\section{REFERENCES}

Dadson, S., N. Hovius, S. Pegg, W.B. Dade, M.J. Horng, and H. Chen. 2005. Hyperpycnal river flows from an active mountain belt. Journal of Geophysical Research 110, F04016, http://dx.doi.org/10.1029/2004JF000244.

Draut, A.E., G.C. Kineke, D.W. Velasco, M.A. Allison, and R.J. Prime. 2005. Influence of the Atchafalaya River on recent evolution of the chenier-plain inner continental shelf, northern Gulf of Mexico. Continental Shelf Research 25:91-112, http://dx.doi.org/10.1016/ j.csr.2004.09.002

Geyer, W.R., P.S. Hill, and G.C. Kineke. 2004. The transport, transformation, and dispersal of sediment by buoyant coastal flows. Continental Shelf Research 24(7-8):927-949. http://dx.doi. org/10.1016/j.csr.2004.02.006.

Hovius, N., C.P. Stark, H.T. Chu, and J.C. Lin. 2000 Supply and removal of sediment in a landslidedominated mountain belt: Central Range, Taiwan. Journal of Geology 108:73-89, http:// dx.doi.org/10.1086/314387.

Hu, C.-K., C.-T. Chiu, S.-H. Chen, J.-Y. Kuo, S. Jan, and Y.-H. Tseng. 2010. Numerical simulation of barotropic tides around Taiwan. Terrestrial, Atmospheric and Oceanic Sciences 21:71-84, http://dx.doi.org/10.3319/ TAO.2009.05.25.02(IWNOP).

Huh, C.A., W. Chen, F.-H. Hsu, C.-C. Su, J.-K. Chiu, S. Lin, C.-S. Liu, and B.-J. Huang. 2011. Modern ( $<100$ years) sedimentation in the Taiwan Strait: Rates and source-to-sink pathways elucidated from radionuclides and particle size distribution. Continental Shelf Research 31:47-63, http://dx.doi.org/10.1016/ j.csr.2010.11.002. 
Kao, S.J., S. Jan, S.C. Hsu, T.Y. Lee, and M. Dai. 2008. Sediment budget in the Taiwan Strait with high fluvial sediment inputs from mountainous rivers: New observations and synthesis. Terrestrial, Atmospheric and Oceanic Sciences 19:525-546, http://dx.doi.org/10.3319/ TAO.2008.19.5.525(Oc).

Kao, S.J., T.Y. Lee, and J.D. Milliman. 2005. Calculating highly fluctuated suspended sediment fluxes from mountainous rivers in Taiwan. Terrestrial, Atmospheric and Oceanic Sciences 16(3):653-675. Available online at: http://tao.cgu.org.tw/index.php?id=700 (accessed November 1, 2011).

Kao, S.J., and J.D. Milliman. 2008. Water and sediment discharges from small mountainous rivers, Taiwan: The roles of lithology, episodic events, and human activities. Journal of Geology 116:431-448, http://dx.doi.org/ 10.1086/590921.

Lin, C.W., C.L. Shieh, B.D. Yuan, Y.C. Shieh, S.H. Liu, and S.Y. Lee. 2004. Impact of the Chi-Chi earthquake on the occurrence of landslides and debris flows: Example from the Chenyulan River watershed. Engineering Geology 71:49-61, http://dx.doi.org/10.1016/ S0013-7952(03)00125-X.

Liu, J.T., H.-L. Lin, and J.-J. Hung. 2006. A submarine canyon conduit under typhoon conditions off southern Taiwan. Deep Sea Research Part I 53:223-240, http://dx.doi.org/10.1016/ j.dsr.2005.09.012.

Milliman, J.D., and S.J. Kao. 2005. Hyperpycnal discharge of fluvial sediment to the ocean: Impact of Super-Typhoon Herb (1996) on Taiwanese Rivers. Journal of Geology 113:503-506, http://dx.doi.org/ 10.1086/431906

Milliman J.D., S.W. Lin, S.J. Kao, J.P. Liu, C.S. Liu, J.K. Chiu, and Y.C. Lin. 2007. Short-term changes in seafloor character due to flood-derived hyperpycnal discharge: Typhoon Mindulle, Taiwan, July 2004. Geology 35(9):779-782, http://dx.doi.org/ 10.1130/G23760A.1.

Milliman, J.D., and J.P.M. Syvitski. 1992. Geomorphic/tectonic control of sediment discharge to the ocean: The importance of small mountain rivers. Journal of Geology 100:525-544, http://dx.doi.org/ $10.1086 / 629606$.

Nittrouer, C.A., and J.H. Kravitz. 1996. STRATAFORM: A Program to study the creation and interpretation of sedimentary strata on continental margins. Oceanography 9(3):146-152. Available online at: http://tos.org/oceanography/issues/ issue_archive/issue_pdfs/9_3/9.3_nittrouer_ kravitz.pdf (accessed November 1, 2011).

Nittrouer, C.A., D.J. DeMaster, A.G. Figueiredo, and J.M. Rine. 1991. AmasSeds: An interdisciplinary investigation of a complex coastal environment. Oceanography 4(1):37. Available online at: http://tos.org/ oceanography/issues/issue_archive/issue_ pdfs/4_1/4.1_nittrouer_et_al.pdf (accessed November 1, 2011).

Sherwood C.R., J.W. Book, S. Carniel, L. Cavaleri, J. Chiggiato, H. Das, J.D. Doyle, C.K. Harris, A.W. Niedoroda, H. Perkins, and others. 2004. Sediment dynamics in the Adriatic Sea investigated with coupled models. Oceanography 17(4):58-69.

Available online at: http://tos.org/ oceanography/issues/issue_archive/issue_ pdfs/17_4/17.4_sherwood_et_al.pdf (accessed November 1, 2011).

Walsh J.P., and C.A. Nittrouer. 2009. Understanding fine-grained river-sediment dispersal on continental margins. Marine Geology 263(1-4):34-45, http://dx.doi.org/ doi:10.1016/j.margeo.2009.03.016.

Wright, L.D., and C.A. Nittrouer. 1995. Dispersal of river sediments in coastal seas: Six contrasting cases. Estuaries 18:494-508, http://dx.doi.org/ $10.2307 / 1352367$.

Wu, C.-C., and Y.-H. Kuo. 1999. Typhoons affecting Taiwan: Current understanding and future challenges. Bulletin of American Meteorological Society 80:67-80, http://dx.doi.org/10.1175/ 1520-0477(1999)080<0067:TATCUA >2.0.CO;2.

Yu, S.B., L.C. Kuo, Y.J. Hsu, H.H. Su, C.C. Liu, C.S. Hou, J.F. Lee, T.C. Lai, C.C. Liu, C.L. Liu, and others. 2001. Preseismic and coseismic displacements associated with the 1999 Chi-Chi, Taiwan, earthquake. Bulletin of the Seismological Society of America 91:995-1,012, http://dx.doi.org/10.1785/0120000722. 